\title{
ПРЕВОДНАТА РЕЦЕПЦИЈА НА ТВОРЕШТВОТО НА МИГЕЛ ДЕ СЕРВАНТЕС НА МАКЕДОНСКИ ЈАЗИК
}

\author{
Игор Поповски \\ Независен истражувач, Скопје \\ igorpp0711@gmail.com
}

Во овој труд ги разгледуваме преводите на дел од творештвото на Мигел де Сервантес на македонски јазик. Ги следиме првите скратени, лектирни изданија на Дон Кихот̄ од 1950-тите, а потоа критички се осврнуваме на првиот и единствен целосен превод на неговиот најпознат роман, направен во 1985 година од страна на Илија Корубин и Александар Митевски. Се осврнуваме и на Примерни новели, интегрално преведени во 2012 година од Виолета Јагев, а анализираме и стихови од неговите драми и прозни дела

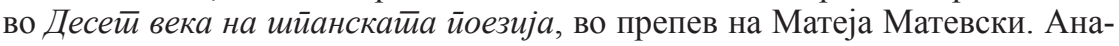
лизата покажува дека творештвото на Сервантес во македонската култура е нерамномерно застапено во споредба со другите имиња од светската книжевност. Со оглед на тоа што „донкихотски“ и „донкихотство“ се дел од македонскиот јазик и се користат во разни контексти, отстапуваме најголем простор за анализа на основните аспекти на интегралниот превод на Дон Кихой на македонски јазик.

Клучни зборови: Мигел де Сервантес, Дон Кихой, Примерни новели, превод, рецепција 


\title{
THE RECEPTION OF MIGUEL DE CERVANTES' LITERARY OUTPUT IN MACEDONIAN
}

\author{
Igor Popovski \\ Independent researcher, Skopje \\ igorpp0711@gmail.com
}

This paper examines the translations of some of Miguel de Cervantes' literary output in Macedonian. I trace the first abridged editions of Don Quijote from the 1950s and critically examine and assess the first and only unabridged edition of 1985 by Ilija Korubin and Aleksandar Mitevski. I also review the 2012 unabridged edition of his Novelas ejemplares, translated by Violeta Jagev, and finally, analyze verses from his plays and prose included in Deset veka na španskata poezija, an anthology of Spanish poetry translated by Mateja Matevski. The analysis shows that Cervantes' literary output is underrepresented in the Macedonian culture, in comparison with other great names of world literature. Considering that the words 'donkihotski' and 'donkihotstvo' form part of the Macedonian language and are used in many contexts, a closer look is taken at the unabridged edition of Don Quijote in Macedonian.

Keywords: Miguel de Cervantes, Don Quijote, Novelas ejemplares, translation, reception 


\section{1 Вовед}

Преводната рецепција на еден автор во една култура може да се смета за камен-темелник за почеток на интертекстуалната мрежа, која потоа се шири во книжевноста, во критиката и, општо, во културата. Македонските околности не дозволиле поран развој на преводната дејност и кај нас најчесто се читало на сродни јазици, поради што секое проучување на рецепцијата на светската книжевност е неминовно приказна што почнува на средината. Македонската книжевна сцена доживува „забрзан развој“ по 1945 година, а тоа го отвора и интересот за „комуникација со други книжевни системи“ (Г'урчинова 2001) и за преведувањето на македонски јазик, за збогатување на македонската култура и за збогатување на македонскиот јазик.

Преводите на творештвото на шпанскиот писател Мигел де Сервантес Сааведра, еден од темелите на модерната книжевност, имаат скромен удел во повоената македонска културна средина; неколкуте важни датуми се како „меѓуигри“ на преведувачката сцена, меѓу големите канонски дела и автори. Всушност, ако ги изземеме многуте скратени лектирни изданија и нивните реизданија од 1951 година наваму (подвлекувајќи ја, сепак, нивната важност за пропагирање на делото на Сервантес), издвојуваме одвај три клучни датуми. Првиот е 1985 година, кога во издание на „Наша книга“ се појавува првиот целосен превод на капиталното дело на Сервантес во два тома, со

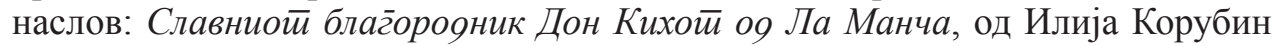
и д-р Александар Митевски, како консултант за шпански јазик и препејувач на стиховите. Вториот датум е 2004 година, кога во издание на МАНУ, а во препев на академик Матеја Матевски, излегува антологијата Десети века на шйанскайа йоезија, во која Сервантес е застапен со четири песни. Третиот датум е 2012 година, кога за првпат излегуваат на македонски јазик Примерни новели, во превод од шпански јазик на Виолета Јагев, дел од проектот „,везди на светската книжевност“, а во издание на „Три“.

Дополнителна причина за задоцнетата преводна рецепција ${ }^{1}$ на творештвото на Сервантес, покрај веќе наведените, е и неразвиеноста на хиспанистиката како научно поле кај нас. Сепак, во време кога литературата на западните народи најчесто доаѓала кај нас преку посредни јазици, зачудува фактот што првиот целосен (посреден) превод на Дон Кихой се појавува дури триесетина години по првите (посредни) преводи на еден Шекспир (споредбено, Васил Иљоски и Илија Милчин ја преведуваат драмата Како шито милувайе во 1949

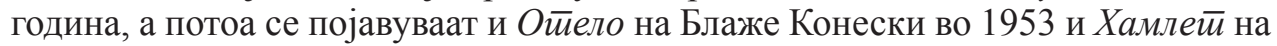
Ацо Шопов во 1960). Но, ако македонската приказна на Шекспир, како само едно од многуте клучни имиња на светската литература, понатаму доживува забрзан развој, Сервантес кај нас уште чекори бавно, несигурно и непрецизно во секое поле на македонската култура.

\footnotetext{
1 За споредба, првиот превод на бугарски јазик од Христо Самсаров датира од 1882 година (Vassileva Kojouharova 2005), а на српски јазик од 1895-6 година од Ѓорѓе Поповиќ (Stojanović 2005).
} 
Целта на овој труд е да се истражат постојните преводи на делата на Сервантес на македонски јазик. Прво, кусо ќе се осврнеме на лектирните изданија на Дон Кихой, а потоа и на првиот и единствен интегрален превод на македонски јазик на ова дело. Имајќи ја предвид обемноста на материјалот, во оваа пригода ќе ги анализираме насловите на двата тома на Дон Кихо $\bar{u}$, кои ќе ни послужат како илустрација за важноста од соодветен превод. Од прозата на Сервантес ќе се осврнеме и на изданието на Примернииее новели, а за крај ќе го анализираме и изборот стихови во антологијата на акад. Матеја Матевски.

\section{2 Прозата на Сервантес}

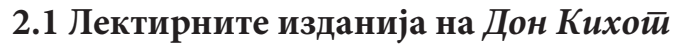

Иако не можеме да го утврдиме најраниот датум од кога класикот на Сервантес почнал да фигурира во списоците задолжителна литература во Македонија, според нашите податоци станува збор за најмалку 70 години континуирано присуство на Дон Кихой како лектира ${ }^{2}$. Сведоштво за тоа дава Благоја Иванов:

Ние, втората литературна генерација во македонската книжевност по војната, излегувавме од школските клупи во годините 1947-1952 [...] Не ги спомнувам овде авторите и делата кои сме ги учеле и читале во школа и од кои дури многу подоцна ќе прочитаме некои во целина, како што е „Дон Кихот“ од Сервантес (1996: 91-92).

Првите лектирни, односно скратени изданија на Дон Кихой на современ македонски јазик се појавуваат во раните 1950-ти години на минатиот век. Во 1951 година во издание на „Кочо Рацин“ излегува првото скратено издание од романот на Сервантес, на само 68 страници, во превод од бугарски јазик на Нада Конеска. Истата преведувачка ке ги потпише и следните две лектирни изданија, во 1953 и во 1956 година, додека во 1958 излегува попроширена верзија од романот, на 139 страници, во превод на Благоја Корубин. Во 1976 година Димитар Гогушевски прави избор на поглавја од Дон Кихой на 159 страници, во издание на „Наша книга“, а тоа е препечатено и во 1995 година.

Во 1996 година се појавува скратена, лектирна верзија од преводот на Илија Корубин и Александар Митевски во издание на „Детска радост“. Верзии од тој превод се објавуваат и во 1999 и во 2002 година. К'е издвоиме уште три нови скратени преводи: во 2003 во издание на „Феникс“ е објавен превод потпишан од Зорица Димитровска; во 2007, пак, од истата издавачка куќа излегува превод од Павлина Димитровска и Светлана Ивановска; во 2010 година, според библиотечните податоци на COBISS, „Просветно дело“ печати поширок избор од романот на Сервантес, на 313 страници, во превод од српски на Билјана Јованчева. Последново издание за првпат има поинаков наслов од

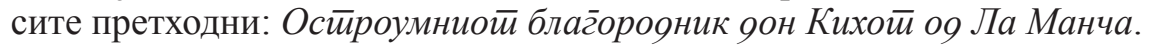

\footnotetext{
${ }^{2}$ Дон Кихой сѐ уште фигурира како лектира во средните училишта.
} 


\section{2 Првиот и единствен целосен превод на Дон Кихой}

Најпознатото дело на Сервантес, Дон Кихой, за првпат излегува во интегрално, двотомно издание, во 1985 година. Истиот превод добива двотомно реиздание во 2010 година од страна на „Бегемот“, и четиритомно реиздание во 2015 година, како дел од проектот „,везди на светската книжевност“ од страна на „Арс Ламина“. Вреди да се спомене дека двата тома бројат над 300 фусноти, кои изобилуваат со дообјаснувања и со појаснувања од страна на преведувачот или на преведувачите. Изданијата од 1985 и од 2010 немаат дополнителен критички текст, додека во изданието од 2015 година фигурира поговор од Санде Стојчевски.

Во првото издание од 1985 не е наведен јазикот од кој преведувал Илија Корубин; во реизданието од 2010 е наведено дека преводот на Илија Корубин е направен од шпански јазик, а е изоставен консултантот Александар Митевски; во последното реиздание од 2015 година стои дека преводот е направен од руски јазик. Сепак, според нашите првични компаративни проверки, македонскиот Дон Кихой е барем делумно направен со посредство на бугарскиот превод на

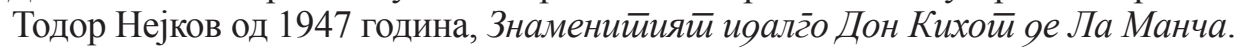

Во овој текст, поради очигледната неможност да навлеземе во детална анализа на целиот превод на Дон Кихо $\bar{u}$, се решивме да дадеме податок за насловите на двата дела, со цел да ја илустрираме оваа мошне сложена проблематика, која несомнено бара многу поголем простор и посеопфатен пристап. Критиката на македонскиот превод мора да се направи имајќи го предвид фактот дека, сепак, станува збор за посреден превод.

Насловот на двата дела на македонски гласи: Славниой благоорояник Дон Кихот̄ og Ла Манча, иако оригиналниот наслов на првиот дел, односно првиот роман, објавен во 1605 година, гласи: El ingenioso hidalgo don Quijote de la Mancha, а на вториот дел, односно на вториот роман, објавен во 1615 година, гласи: El ingenioso caballero don Quijote de la Mancha.

Да започнеме од придавката ingenioso, присутна во двата наслова, која е мошне далеку од „славен“. Според речникот на Шпанската кралска академија, зборот ingenio значи првенствено „способност на човекот да размислува и измислува брзо и лесно“, како и „интуиција, разбирање, поетски и творечки вештини““3. Значи, дефинициите предлагаат спој од она што обично го сфаќаме како интелигенција и креативност. Уште позначајна е дефиницијата што ја дава Коварубијас во првиот речник на шпанскиот јазик, Tesoro de la lengua castellana, o española, кој излегува во 1611 година, помеѓу двата дела на Дон Kuxoū, a тоа е дека ingenio е „природна умствена сила, која го испитува она што со помош на разумот и на расправата може да се достигне во сите видови науки, дисциплини и слободни уметности, итроштини, измислици и измами“ (Covarrubias 1611). Со ова, уште веднаш можеме да ги земеме како недоволно соодветни зборовите „остроумен“ и „бистроумен“ како можни преводни еквиваленти ${ }^{4}$. Потребно е да се изнајде нијанса што би ги покривала еднак-

\footnotetext{
${ }^{3}$ Извор: https://dle.rae.es/ingenio?m=form (Пристапено на: 14.10.2020)

${ }^{4}$ Дополнителен проблем така би ни отвориле и концептите agudezalagudo, кои се подеднакво важни во шпанскиот барок, а се многу поблиски до тие значења. И пребарувањето според си-
} 
во креативноста, итроштината и интелигенцијата на човековиот ум. За овој проблем, во контекст на српските изданија на Дон Кихош̄, говори и Лилјана Павловиќ-Самуровиќ (Pavlović-Samurović 2004: 224-230), чиј заклучок е дека зборот велеумни најдобро ги покрива дефинициите што ги има придавката ingenioso. Со оглед на тоа дека префиксот веле- се користи и во македонскиот јазик (велемајстиорски, велегрраяски), на мислење сме дека зборот „велеумен“ би можел да биде прифатен како посоодветен преводен еквивалент ${ }^{5}$.

Зборовите ingenio/ingenioso се појавуваат повеќепати во романот - само во прологот Сервантес ги употребува трипати, а нашиот преведувач во сите три контексти ги превел различно: прво како „бесплоден и недостатно образован ум“ (estéril y mal cultivado ingenio) (Сервантес 2010 I: 7), па како „мудра пристојност“ (un decoro tan ingenioso) (ibid., 9), а потоа и како „најостроумниот човек“ (el más ingenioso) (ibid., 13). Се појавува и во насловите на втората и на шестата глава од првиот дел, каде што преведувачот решил да го остави „славниот“ (ibid., 40, 72), а кога повторно се споменуваат зборовите во осмата и во тринаесеттата глава, ги наоѓаме преводите ,умовите во Ла Манча“ (los ingenios de la Mancha) (ibid., 99), „светол ум“ (el ingenio) (ibid., 141). Во вториот дел на Дон Кихой, пак, кога во второто поглавје за првпат се споменува целосниот назив на првиот дел, преведувачот останува доследен на своето решение, односно на решението понудено во посредниот превод, па го менува значењето на ingenioso: ,'Славниот благородник...'“ (Сервантес 2010 II: 31).

Проблематичен е и зборот hidalgo, бидејќи означува припадник на пониското, осиромашено благородништво. Поради оваа нијанса, некои преведувачи се решаваат за транслитерација на терминот: ияалг̄o. Проблемот со титулата на Дон Кихот станува уште посериозен кога треба да го преведеме насловот на вториот дел, оригинално објавен десет години по првиот (во 1615 година), кој на шпански гласи: El ingenioso caballero don Quijote de la Mancha. Веднаш се забележува дека, наместо зборот hidalgo, фигурира зборот caballero и тоа не е воопшто случајно: ако зборот hidalgo од првиот дел значи 'низок благородник', caballero е повисок ранг во строгата општествена хиерархија и значи 'витез'. Причините поради кои вториот дел носи поинаков наслов од првиот дел се предмет на толкување на сервантистите: една теорија е дека авторот решава иронично да го унапреди нискиот благородник (или: ияалг̄ō̄o) во витез, поради неговите подвизи во првиот дел, и покрај тоа што е тоа невозможно ${ }^{6}$. Но, можеби најприфатлива е теоријата дека причините за промената се од попрактична природа - имено, една година пред Сервантес да го објави вториот дел, во Шпанија анонимно бил објавен втор, апокрифен дел, насловен Segundo tomo del ingenioso hidalgo don Quijote de La Mancha, a

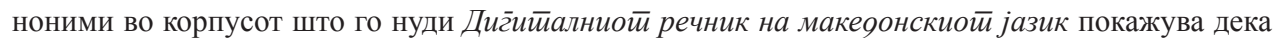
значењето на зборот 'остроумен' е синонимно со ‘бистар', ‘интелигентен', ‘луциден'.

5 За „велеумен“ се определува и Прокопиев во еден пасус од својот есеј Бийка со ветеернииа (2014).

${ }^{6}$ Мартин де Рикер образложува зошто Дон Кихот не е и никогаш не би можел да биде витез: според законите на Алфонсо Х Мудриот, кои биле на сила и тогаш, витез не може да стане оној што се здобил со таа титула по пат на исмевање (епизодата со крчмарот во I, 3), а не може да стане ни оној што е луд ни оној што е сиромав (Riquer 1970: 86-89). 
потпишан од извесен Алонсо Фернандес де Авељанеда 7 . Промената на рангот на Дон Кихот можеби е начинот на кој Сервантес сакал да се разликува неговиот втор, автентичен дел, од апокрифниот втор дел на Авељанеда (Riquer 1970: 176).

Без разлика на причините, насловот на вториот дел е поинаков и тоа треба да биде одразено во преводот. Македонското продолжение на Дон Кихоти го носи истиот наслов како и првиот дел ${ }^{8}$, што е неприфатливо - не само затоа што така гласи оригиналот туку и затоа што меѓу објавувањето на првиот и на вториот дел од романот изминуваат десет години и се забележува изразита промена во стилот, во јазикот и во темите меѓу едниот и другиот дел - толку, што некои критичари претпочитаат да ги гледаат како два засебни романи.

„Слободниот“ превод на насловите на Дон Кихой не ја губи ироничноста и хумористичноста на оригиналните наслови. Сепак, со избраниот наслов се губат исклучително важни податоци, кои го карактеризираат ликот на Дон Кихот, а кои се значајни во однос на развојот на дејството и со тоа претставуваат насоки за посоодветно толкување. Би напоменале дека со оваа подробна анализа на насловот не сакаме да се стекне впечаток дека преводот на Корубин и Митевски е во целост несоодветен. Целта ни е да ја истакнеме големата потреба за критички пристап кон единствениот превод на Дон Кихой на македонски јазик и уште поголемата потреба ова дело да добие нов превод од шпански на македонски јазик.

\section{3 Примерни новели}

За Примерниие новели најважна година е 2012, кога во рамките на проектот „Хвезди на светската книжевност“ се објавува целокупната Сервантесова збирка. Преводот од шпански на Виолета Јагев ${ }^{9}$ зафаќа 492 страници и ги содржи сите единаесет, односно дванаесет новели, според редоследот од првото издание од 1613 година: „Младата циганка“ (“La gitanilla”), „Beликодушниот љубовник“ (“El amante liberal”), „Ринконете и Кортадилјо“ ("Rinconete y Cortadillo”), „Шпанката Англичанка“ ("La española inglesa”), „Правникот Видриера“("El licenciado Vidriera”), „Силата на крвта““("La fuerza de la sangre”), „Љубоморниот Естремадурец“ (“El celoso extremeño”), „Славната садомијачка““ (“La ilustre fregona”), „Двете девојки“ (“Las dos doncellas”), „Госпоѓa Корнелија“ (“La señora Cornelia”), „Брак врз измами“ (“El casamiento

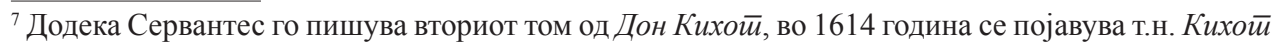
на Авељанеgа. Ова претставува пресвртница во развојот на настаните: имајќ ја предвид автореференцијалноста на вториот дел на Дон Кихой (ликовите во книгата знаат за постоењето на првиот дел и го препознаваат Дон Кихот како јунакот од романот), Сервантес го инкорпорира објавувањето на апокрифното продолжение во своето продолжение, при што и самиот Дон Кихот дознава за тоа од други ликови, жестоко го критикува Авељанеда и решава да ја смени својата дестинација за да се разликува од својот лажен двојник.

8 За да биде ситуацијата уште подонкихотовска, на задната корица од реизданието на „Бегемот“", на која има куса белешка за ликот и делото на Сервантес, наведен е насловот: Умислениой благоорояник Дон Кихой оя Манча.

9 За овој превод Виолета Јагев ја добива наградата „Ванѓа Чашуле“, која ја доделува Сојузот на литературните преведувачи (cf. Дневник, 30.09.2012).
} 
engañoso”) и новелата што е вметната во неа, „Разговор меѓу Сипион и Берганза“" ("Coloquio de los perros"), која традиционално се смета за засебна новела. Во изданието фигурираат и прологот на Сервантес и посветата на Дон Педро Фернандес де Кастро. Изданието има 431 фуснота, во која се објаснуваат термини, нијанси во значењето, личности и дела. Еднакво важно е да се спомене дека овој превод има и поговор од Ацо Пероски: „Помеѓу дидактичноста и литерарноста: за универзалните вредности во Примернииее новели на Сервантес“. Пероски дава воведен податок за животот и делото на Сервантес, а потоа и белешка за насловот на ова дело; ја истакнува дидактичната функција на $\bar{u} р и м е р н о \bar{\imath} о$, но и естетичката функција на убавото (бидејќи и самиот Сервантес вели дека ги дава новелите за разонода и забава на народот). Пероски заклучува дека „според тенденциите, според книжевната вредност и според жанровско стилските карактеристики, Примерни новели недвосмислено го следат примерот на Декамерон...“ (2012: 488).

Иако не е наведено изданието според кое е направен македонскиот превод, анализата на новелата „Брак врз измами“, заедно со „Разговор меѓу Сипион и Берганза“, која е составен дел од претходно споменатата, но по традиција се смета за посебна новела, открива дека станува збор за издание направено според првото од 1613 година, а не според подоцнежните, чии разлики не се среќаваат во нашиот превод. Сепак, проблематично е што не е наведено конкретното издание според кое е направен нашиот превод, бидејќи може да се забележи важна разлика на преминот од „главната“ новела („Брак врз измами“) кон вметнатата („Разговор меѓу Сипион и Берганза“). Имено, во македонското издание, како крај на првата новела е земен последниот дијалог меѓу Кампузано и Пералта, кој треба да се појави на крајот од вметнатата новела, а вметнатата новела почнува и завршува само со дијалогот меѓу пците.

Дополнителна разлика е што во македонскиот превод не се вклучени четирите пофални песни по посветата и прологот: три сонети посветени на авторот од маркизот од Алкањисес, Фернандо Бермудес Карвахал и дон Фернандо де Лодења, и еден сонет посветен на читателите од Хуан де Солис Мехија.

Ни се чини соодветно да известиме и за едно издание на издавачката куќа „Феникс“ од 2001 година, насловено: Две яевојки: љубовен лавиринй, на 56 страници. Иако направивме неколку обиди да дојдеме до ова издание, не успеавме во намерата. Според насловот, станува збор за превод на новелата "Las dos doncellas” од односната збирка. Во базата на податоци COBISS не е наведено кој е преведувачот на ова дело.

\section{3 Стиховите на Сервантес}

Она што го одвоивме како втор позначаен датум во македонската рецепција на Мигел де Сервантес, е објавата на најсеопфатната антологија на шпанска-

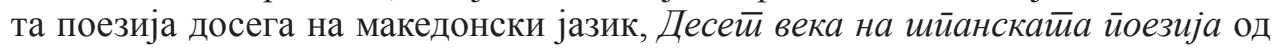

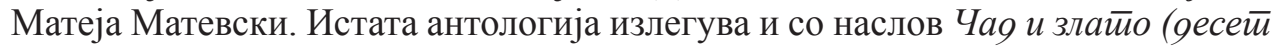
века на шиианскайа йоезија) во 2005 година, во издание на „Матица“, а Сервантес е присутен со истиот избор и во Шйанска йоезија на ренесансайа и барокой (,Три“, 2013). 
Вреди да се повтори дека Матевски, како сестран ерудит, е најдоследниот проследувач на шпанската поезија во Македонија. Овој антологиски потфат опфаќа поезија од раните мосарапски харчи до најновите текови на шпанската поезија во XX век. Во антологијата Матевски му дава скромен простор и на Сервантес (стр. 167-170) со четири лирски композиции, бидејќи смета дека „во своите стихови што ги вградувал во својата проза, тој го изразува духот и сензибилитетот на своето време во драматичните општествени и духовни промени во Шпанија““ (2004: 29), како и дека „како поет се одликува со суптилен и музикален израз на длабок сензибилитет, но не го достига нивото на своите прозни дела“" (ibid., 167).

Всушност, иако е точно тоа дека Сервантес вметнува стихови во своите прозни дела, во оваа антологија поместени се три извадоци од стихуваните драми на Сервантес - што, меѓу другото, претставува прв и единствен превод на извадок од неговите драми - и само една песна од неговата проза, поточно од новелата "La gitanilla".

Првата песна со која е застапен Сервантес во антологијата е песната на Амбросио, односно Каталина, од Los baños de Argel (Алжирскийе зайвори), која почнува со стихот „Aunque pensáis que me alegro“ (Cervantes 2016: vv. 1140-1451). Песната е сехел (zéjel), шпански поетски облик што се состои од рефрен, варијација и повторување на дел од рефренот. Препевот на Матевски, „Иако мислите дека сум весел...“ е послободна интерпретација на овој поетски облик: осмерецот на Сервантес не е задржан во сите стихови, римата не ја следи шемата на Сервантес, а и стихот од рефренот што се повторува трипати („conmigo traigo el dolor“), добива три варијации во препевот.

Втората песна е извадок од една од најдобрите драми на Сервантес, Pedro de Urdemalas (Пеоро ge Уряемалас). Кон самиот крај има музичари што пеат романсиљо (romancillo), кратка песна составена од шестерци, варијација на најпознатиот шпански поетски облик на народна поезија, романсата (romance), која е составена од осмерци. Матевски варира со должината на стихот, но доминира шестерецот. Асонантната рима во парните стихови е задржана.

Третата и четвртата песна се сонети, составени од 14 единаесетерци, co рима: ABBA ABBA CDE CDE. Првиот сонет е изваден од новелата "La gitanilla” („Младата циганка“) ${ }^{10}$, „Cuando Preciosa el panderete toca“, односно на македонски: „Убавката кога на дајрето чука...“ Вториот сонет е извадок од самиот крај на првиот чин од драмата La gran sultana (Величестивенайа сул-

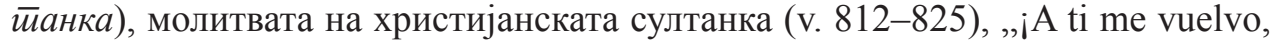
Gran Señor", која во антологијата е наведена како Soneto - oración и преведена соодветно: Сонети - молийва. Матевски и овде зема поетска слобода во препевот, па затоа римата, сепак, функционира по свои правила и во двата сонети, иако се направени очигледни обиди што повеќе да соодветствува со оригиналот. Единаесетерецот е заменет и во двата сонета со дванаесетерец, кој е редовен, освен во два стиха од Соней-молийва.

\footnotetext{
${ }^{10}$ Сонетот, се разбира, е преведен и во целосното издание на Примернииее новели (Сервантес
} 2012: 44). 
Како што веќе потенциравме, изборот од лириката на Сервантес во оваа антологија е исклучително скромен и ни одблизу не ги претставува поетските и версификаторските способности на Сервантес. Исто така, би било исклучително корисно да биле наведени изворите на делата од кои се извадени претставените стихови за да има македонскиот читател увид во поширокото творештво на Сервантес, сѐ уште непознато за нас. Сепак, за пофалба е овој прв обид да се пренесе на македонски јазик дел од поезијата на Сервантес, особено затоа што тоа доаѓ од перото на еден од најдобрите македонски поети.

\section{4 Заклучок}

Најславниот лик на Сервантес, оној што - како што често се вели - е поголем од својот автор, живее и во македонската книжевност и култура. Дон Кихой е присутен уште од раните повоени години и остава скромен, но видлив печат во сите сфери на културата. Денес мошне често се среќаваат синтагмите изведени од тој роман (,донкихотски“, „донкихотство“, „донкихотизам“ и „донкихотштина“ се дел од македонскиот јазик), често се споменува најславната сцена со ветерниците како синоним за наведените синтагми, а неретка е и употребата на имињата на главните јунаци во културата и во медиумите (Михајловиќ-Костадиновска 2016). За жал, тоа не е случај и со одличните Примерни новели, кои се присутни во својата интегрална верзија веќе осум години. Нашите истражувања не открија значаен прием на новелите во македонската средина.

Од податоците што ги обработивме во оваа статија можеме да заклучиме дека богатото творештво на Мигел де Сервантес не е доволно застапено во превод на македонски јазик. Опусот на Сервантес е многу пообемен од она што е достапно во превод, а и тоа треба да биде подложно на посеопфатна критичка анализа. Особено во случајот со Дон Кихой, покрај систематска анализа на постојниот превод, потребно е да се направи и нов, директен превод од шпански јазик. Повторно ќе ја подвлечеме важноста на преводот и, особено - на добриот превод, како неизоставен прв чекор во рецепцијата на светската литература кај нас. Историјата на современата македонска книжевност би била нецелосна без поглавје за важноста на преводната дејност во повоениот период. Преводот ни денес не губи од својата важност, како за македонската книжевност така и за македонскиот јазик, а творештвото на Сервантес треба да биде посериозно вклучено во таа приказна.

\section{Библиографија}

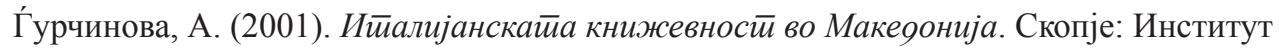
за македонска литература.

Иванов, Б. (1996). Нашата лектира во педесеттите години. Во М. Ѓурчинов и Б. Пет-

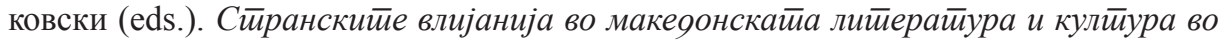

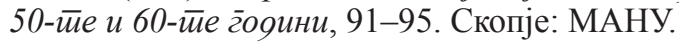

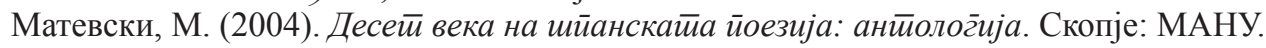


Михајловиќ Костадиновска, С. (2016). Метафорите за Дон Кихот во македонски контекст. Во Д. Кузмановска et al. (eds.). Филко, 1: 591-603. Штип: Универзитет „Гоце Делчев".

Прокопиев, А. (2014). Битка со ветерница (белешки од бојното поле). Книжевна академија, (3-5): 55-70. Скопје: Македонија презент .

Сервантес, М. (2010). Дон Кихот, II тома. Илија Корубин и Александар Митевски (прев.). Скопје: Бегемот.

Сервантес, М. (2012). Примерни новели. Виолета Јагев (прев.). Скопје: Три.

Сервантес, М. (2015). Дон Kихот (I -IV). Илија Корубин и Александар Митевски (прев.). Скопје: Арс Либрис.

Cervantes, M. (2016). Teatro completo. Florencio Sevilla Arroyo (ed.). Barcelona: Penguin. Pavlović-Samurović, Lj. (2004). Knjiga o Servantesu. Beograd: Naučna KMD.

Riquer, M. (1970). Aproximación al Quijote. Barcelona: Teide.

Stojanović, J. (2005). Servantes u srpskoj književnosti. Beograd: Zavod za udžbenike.

Covarrubias, S. (1611). Tesoro de la lengua castellana, o española. [Online] Available from : https://archive.org/details/tesorodelalengua00covauoft/page/155/mode/2up [Accessed: August $\left.24^{\text {th }}, 2020\right]$

Vassileva Kojouharova, S. (2005). Las traducciones de El Quijote al búlgaro. [Online] ¿Qué Quijote leen los europeos?. Actas del IULMYT. Available from: https://cvc.cervantes.es/ lengua/iulmyt/pdf/quijote/15 vassileva.pdf [Accessed: August $24^{\text {th }}, 2020$ ]

Архива на македонските on-line медиуми 2000-2012: https://time.mk/arhiva/

COBISS: http://www.mk.cobiss.net/

Дигитален речник на македонскиот јазик: http://makedonski.info/

Diccionario de la lengua española: https://dle.rae.es/ 
